\title{
Life tables founded upon the discovery of a numerical law regulating the existence of every human being
}

\section{T.R. Edmonds B.A.}

To cite this article: T.R. Edmonds B.A. (1832) Life tables founded upon the discovery of a numerical law regulating the existence of every human being, Philosophical Magazine Series 3 , 1:3, 204-207, DOI: $10.1080 / 14786443208647873$

To link to this article: http://dx.doi.org/10.1080/14786443208647873

曲 Published online: 01 Jun 2009.

Submit your article to this journal $[\pi$

Џلll Article views: 3

Q View related articles $\longleftarrow$ 
siderably less than what I had obtained with the bar of wrought iron, I repeated the experiment with the latter in the same register that $I$ had employed for the former, and obtained the measures of $0^{\circ} 35^{\prime}$ and $2^{\circ} 44^{\prime}$-nearly agreeing with the previous determination : so that there can be no doubt that cast iron expands less than wrought iron, though the rate of increase for the higher temperature appears to be the same in both.

[To be continued.]

\section{Notices respecting Nerw Books.}

Life Tables founded upon the Discovery of a Numerical Law regulating the Existence of every Human Being, \&c. By T. R. EDMonds, B.A., late of Trinity College, Cambridge.

IN

$\mathbf{N}$ this work, of which we have been favoured with a copy, the author announces the discovery of a new law of mortality, which he has applied to the construction of a considerable number of annuity and other tables. The announcement in the title-page, that the tables are founded upon the discovery, instead of the law, is one of those inaccuracies of expression which occur in other parts of the book, and which bespeak carelessness at least on the part of the author, in the construction of his sentences.

The new law is thus announced.-During the succession of years and moments of life, the continuous change in the force of mortality is subject to a very simple law, being that of geometric proportion. But instead of one uniform progression, there are three distinct orders, corresponding respectively to infancy, manhood, and old age. The common ratios of the three geometric series are, we are told, fixed and immutable for all human life in all ages of the world. They are also said to be now first discovered : but it is not stated by what process, nor is it at all important to inquire; for they appear to be wholly empirical, and the tables founded upon them are of no practical value whatever.

Indeed this is the opinion of the author himself. For in page xii. he says, with great truth, that "in all classes of a population the mortality is continually varying." Hence the new fuxed and immutable law cannot be applicable, except at some particular moment, to any of such classes. The author afterwards very justly remarks, that " to generalize from a single fact is absurd; and it is an absurdity of this kind into which those people fall who would apply observations made on one kind of life to all kinds of life." A remark which implies an equal absurdity in applying his own general law, which is fixed for all human life, to any one class or condition of mankind,-or in other words, to any one practical purpose.

But although we concur with the author in the uselessness of his own tables, we dissent from most of his opinions relative to the comparative value of others. 
In page xii. he appears to prefer the Northampton Table, chiefly because it is supported by the name of Dr. Price. But the known incorrectness of this table, or, as our author is pleased to express himself, the "slight inaccuracy of its adjustment of mortality to each age," is not, in his judgement, of any "sensible value in practice ;" yet he afterwards admits that "its applicability to the British population of the present day may fairly be questioned." We believe that the Northampton Table is not capable of affording any accurate measure of life contingencies of any kind; in which respect it so much resembles our author's own offspring, that we are not surprised at its having received from him a kind of fatherly affection.

The Government Table, on the contrary, deduced from the lives of English annuitants, because, as the author says, it "opposesmy theory, as well as that of everyother person", incurs his severe displeasure. A clearly demonstrable fact opposed to a favourite theory is, we admit, vexatious enough, and more particularly so when the theory is one of our own invention, one of our first-born bantlings, and one upon which our hopes of reaping a full harvest of renown has been anxiously founded. So harassing indeed has this opposition of the Government Table to our author's theory been to his feelings, that he would hurl the Table and its author to perdition together, with perhaps the printer and his devils into the bargain.

His method, however, of disposing of the author is not marked by that precision which we should have expected from a B.A. of Trinity College, Cambridge. He says, "the reported mortality of English annuitants is not entitled to much confidence," because it " rests upon the authority of a person whose qualifications for the task undertaken are unknown to the public." But the reported mortality is that which appears in the records preserved in the Government offices, and does not rest upon the authority of any person except as a transcriber, whose only requisite qualifications are, that he should be able to read and write, and, as school-boys term it, do a sum in Addition. We will, however, deal fairly with Mr. Edmonds, and not pin him down to his own loose expression, " reported mortality," but will help him to a phrase, which if any distinct meaning pervaded his mind when he wrote the passages we have just quoted, may perhaps represent that meaning. He possibly intended to say that the reported probability of life, among the English annuitants, is not entitled to much confidence, because the qualifications of the person deducing it are unknown to the public.

Now, of all the reasons we have ever heard for discrediting the result of a rather complicated arithmetical process, this is the most. futile and absurd :- because the qualifications of the author are $u n$ known to the public. Why upon this principle, the Tables of Mr. Edmonds might, even if they were really good for anything, flap their leaden wings to the end of time without attaining even the lowest degree of public confidence. For what do the public know of this gentleman's qualifications ? But we will ask him what he means by the public? We much suspect that in his vocabulary it signifies only the individual occupant of his own chambers. We shall, however, construe the phrase according to its ordinary acceptation, and shall 
suppose our public divided into three classes: the first consisting of those who from personal acquaintance with the author of the Government Tables have had an opportunity of ascertaining his qualifications for the task of framing them; the second, those who have read his Report, printed by order of the House of Commons, March 31,1829, and are capable of forming a judgement of the author's fitness from that report; and the third, those who neither know nor care any thing about such matters. Now we have not the least hesitation in affirming, that the first two of these classes do know the competency of the author to perform his task ; and in confirmation of this assertion, we shall quote an authority which we believe Mr. Edmonds himself will not dispute. In a paper by Mr. Lubbock, in the third volume of the Cambridge Philosophical Transactions, and in p. 330, Mr. Edmonds will find the following passage : " $\mathrm{Mr}$. Finlaison has very recently published extensive tables of mortality, formed from theGovernment tontines and annuitants, which are rendered equally valuable by the accuracy of the materials from which they have been deduced, and the very great care and attention which lias been bestowed on them by the author." After this, we apprehend we should only waste the time of our readers by pursuing this subject further.

We have already expressed our dissent from many of the doctrines and opinions of this author: there are, however, some in which we readily concur; as those in which we are taught that "good air is as necessary to health as good food," and that "the increase of a population has a great dependence upon the number of women at the childbearing age," and others equally conspicuous for their truth, and their beautiful simplicity, as general laws.

We must now limit ourselves to a very few more observations. Our author says, p. xxi. " The check on the exertion of the prolific power is scarcity of food." We apprehend his meaning to have been, that scarcity of food abates the prolific power. But let him look to Ireland, with its scanty means of subsistence, and its overflowing population; and he may also discover, when he sets about observing facts instead of building theories, that the largest families are upon an average produced by the poorest classes.

We are told, p. $\mathrm{xxx}$. that " the circumstances most favourable to vitality consist in alternations of privation and saturation:"-to starve one day, and feed to repletion on the next. We, however, seriously recommend our author, and particularly at this time, not to trust his own vitality to such an experiment.

And in p. viii. we have the comfortable doctrine announced, that " the hopes of an indefinite prolongation of the term of human life have now ceased to be visionary," and this, we presume, without the assistance of the Hermetic philosophy.

We suspect that "too much learning" has exercised an unwholesome influence on the mind of our author, who is probably young, with an active and uncurbed imagination, which he has permitted on this occasion to hurry him into as many scrapes as the wild steed of Mazeppa did his unwilling rider. But although we have thus amused ourselves, and perhaps our readers, at the author's expense, we can assure him that we do not entertain the slightest un- 
friendly feeling towards him; and although an entire stranger to us, we wish him every success in his laudable endeavour to build up an honourable reputation for himself: yet we earnestly counsel him not again to attempt the destruction of that of his neighbour; as it betrays both bad taste and bad feeling, and may eventually convert into personal enemies those who might otherwise become useful friends.

On Suspension Bridges; containing an Inquiry into the proper Forms of their Catenaries; with Remarks on the Menai Bridge, and that at Broughton; as likewise some Account of the Failure of the latter. By Eaton Hodgrinson, Manchester, 1831.

In the eastern parts of the world, rope and chain bridges of large span have for a long period been in use; but in Europe the adoption of bridges of suspension is of comparatively modern date, and has opened a new and interesting field for inquiry and experiment, both for the engineer and the mathematician, and has rendered of practical importance the theory of the catenarian curve. During the last century, mathematicians investigated many of the properties of this curve; but the addition of the materials which are necessary to form the roadway, and to insure sufficient strength for the variable and large loads of transit, have added new data to the problem.

Mr. Eaton Hodgkinson has, in the present treatise, given a very clear abstract of the properties of this curve under all the probable variations it is liable to in its application to bridges of suspension; not only when the substance of the chain is of uniform strength, but also when the strength varies as the strain,-concluding with an example upon assumed data.

The neat and elegant manner observed throughout renders the tract a desirable object in the library of the practical engineer.

The second part of the work contains an account of the chain bridge at Broughton, near Manchester, with a particular estimate of the strain upon the various parts as compared with the strength, and aiso some important information on the form of the joints of the links ; to which are added some observations on high tests, and on defective welding of the bars.

Next follow a few remarks on the Menai Bridge, showing that it possesses sufficient strength to support seven times its own weight.

An Appendix is given, containing remarks and observations on the cause of failure of the bridge at Broughton, after standing some years, but which has since been repaired and made more secure*.

Theoretical and Experimental Researches to ascertain the Strength and best Form of Iron Beams. By the same Author.

The builder and engineer will find in this treatise many important experiments, conducted with great skill, and described with accuracy of detail. It should be read by every person who intends to use iron beams. The author has long been known for his abilities as a mathematician, and his application of those abilities to practical purposes.

* An account of the fall of the Broughton Suspension Bridge, with some particulars of the causes of its failure, were given in Phil. Mag. and Annals, N.S. vol. ix. p. 384. 